\title{
Monitoring and Investigating Methane Leakage in Coal Gas Production
}

\author{
Xiaohua Ge ${ }^{1,2}$, Jianchao $\mathrm{Ma}^{3}$, Liping Chang ${ }^{1, *}$, Jin Yuan ${ }^{2}$, Xudong $\mathrm{Su}^{2}$, \\ Hengkang Wang ${ }^{2}$, Yuqiang Xiao ${ }^{3}$
}
${ }^{1}$ College of Chemistry and Chemical Engineering, Taiyuan University of Technology, Taiyuan 030024, P.R.China
${ }^{2}$ Research Center for Eco-Environmental Sciences in Shanxi, Taiyuan 030009, P.R. China
${ }^{3}$ College of Mining Technology, Taiyuan University of Technology, Taiyuan 030024, Shanxi, P.R. China

\author{
Received: 15 January 2016
}

Accepted: 9 February 2016

\begin{abstract}
The Qinshui Basin in Shanxi Province in northern China is currently the largest production area of coal bed methane (CBM) in China. For this study, methane $\left(\mathrm{CH}_{4}\right)$ measurements were collected from 113 wellheads to determine primary gas leakage locations. The results indicate that the leakage is primarily from water outlets and tubing; three leakage points accounted for $95.79 \%$ of the total measured gas. With respect to measurement variability, the standard deviation for gas measurements of the tubing was the largest at 12.28. Wells with good geological conditions and scientific management exhibited very low leakage. In contrast, wells with unfavorable geological conditions and improper management had much higher leakage values. The standard deviation of leakage at the water outlets was the next lowest. The role of different processes and running states had the greatest role in $\mathrm{CH}_{4}$ leakage. The leakage from horizontal wellheads was the highest, with an average rate of $20.80 \mathrm{l} / \mathrm{min}$, compared to the average of leakage from flowing wells at $0.88 \mathrm{l} / \mathrm{min}$; this is far below that of the wells that used mechanical gas pumping. The overall emission factor of the 113 examined wells was $176 \mathrm{~kg} \mathrm{CO}_{2}-\mathrm{e} \mathrm{t}^{-1}$, which was far greater than the previously reported Australian emission level (11.7 $\left.\mathrm{kg} \mathrm{CO}_{2}-\mathrm{e} \mathrm{t}^{-1}\right)$.
\end{abstract}

Keywords: coal bed methane, leakage, methane, emission factor

\section{Introduction}

Coal bed gas (CBG) refers to a form of gas that exists in coal seams. It is mainly composed of methane (also referred to as coal bed methane or CBM). The gas is absorbed on the surface of the coal matrix; part of it dissociates from coal pores within the coal, while part of it dissolves into hydrocarbon gas in coal bed water $[1,2]$. Coal bed gas is an important energy resource because of

*e-mail: lpchang@tyut.edu.cn gwmqt1@163.com the increasing demand for gas as a substitute for coal and oil in generating electricity [3].

Coal bed methane resources in China are abundant; the volume of this geological resource in China is surpassed only by Russia and Canada [4]. CBM industry development is important to improve the energy productionconsumption structure and work safety conditions of coal mining activities. Also, CBM is important for relieving the current shortage in China's natural gas supply [5].

As Fig. 1 shows, there are nine major CBM basins in China: Odors, Qinshui, Junggar, Diandongqianxi, Erlian, Tuha, Tarim, Tianshan, and Hailaer. Each basin has a geological reserve of more than $1 \times 10^{12} \mathrm{~m}^{3}$ with a total 


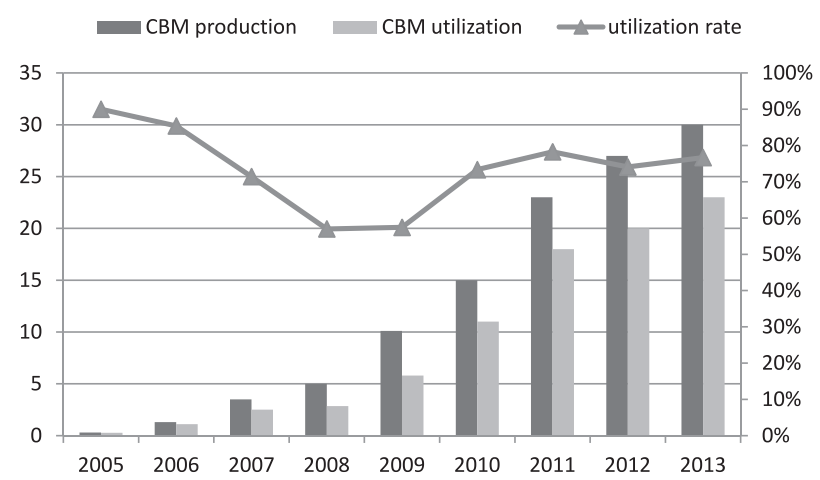

Fig. 1. The development and utilization of CBM in China.

reserve of $30.9 \mathrm{Tm}^{3}$. This represents $84 \%$ of the total CBM resources in China [6].

CMB development in China has increased significantly over the past decade (Fig. 2). Until 2005, China's CBM production was $3 \times 10^{8} \mathrm{~m}^{3}$ (Fig. 1); after this, production increased to $300 \times 10^{8} \mathrm{~m}^{3}$. This increased production mainly occurred in Shanxi province, where local production was $287 \times 10^{8} \mathrm{~m}^{3}$. This represents $95.7 \%$ of the total production in China. In 2013, this percentage increased to $99 \%$, with an average annual growth rate of $77.6 \%$.

A major environmental impact of the CMB industry is methane emissions. Methane is recognized as a greenhouse gas (GHG) that likely plays a role in global warming. Methane traps heat in the atmosphere more effectively than carbon dioxide by a factor of 20 or more
$[7,8]$. The CBM utilization rate is currently no more than $80 \%$ in China, an increase from $76.7 \%$ in 2013 . Therefore, analyzing sources of $\mathrm{CH}_{4}$ leakage and reducing these leakages during the $\mathrm{CBM}$ development process is vital to maximize resource use with respect to energy, economic, and environmental concerns.

With the rapid development of the unconventional gas industry, research on methane leakage is emerging as a study area [9-11]; however, we have identified only two studies that have focused on leakage in CBM development. Recently, researchers in Australia measured unintended (or fugitive) emissions from equipment and well casings in Australian CBM production facilities. United States researchers used a top-down method at the field scale, collecting total atmospheric measurements and then attributing these to sources. This research found discrepancies with the bottom-up estimates. However, considering these countries' differences in geological conditions and technology systems, study results may have limited application to China.

The site for this study, the Qinshui Basin of Shanxi Province in northern China, is currently the largest production base for CBM in China. Methane measurements of 113 wellheads were performed to assess leakage conditions and contributing factors. First, leakage conditions and related factors of different sources were analyzed. Secondly, $\mathrm{CH}_{4}$ leakage from different production technologies and running states were compared. Finally, the comprehensive $\mathrm{CH}_{4}$ leakage rate of the CBM wells was analyzed and the leakage factor estimated.

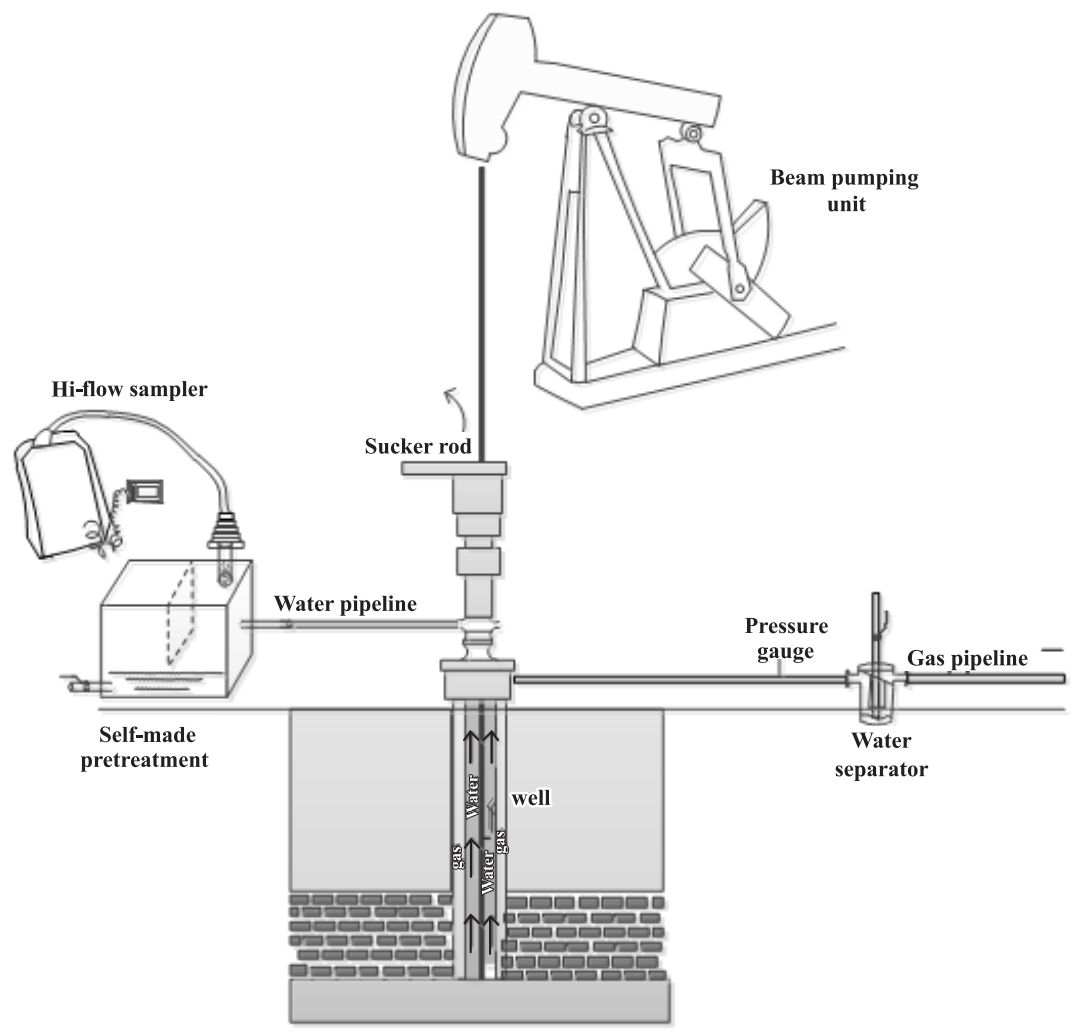

Fig. 2. System boundary of this study. 
Table 1 . The basic situation of 113 wells.

\begin{tabular}{|c|c|c|c|c|c|}
\hline Number & Name & Block & $\begin{array}{c}\text { Gas production } \\
\mathrm{m}^{3} / \mathrm{d}\end{array}$ & Technological types & Running state \\
\hline 1 & YH-97 & YH block & 11,830 & Vertical well & pumping \\
\hline 2 & SHx-291 & YH block & 2,810 & Vertical well & pumping \\
\hline 3 & SHx-292 & YH block & 2,693 & Vertical well & pumping \\
\hline 4 & YH-51 & YH block & 4,544 & Vertical well & pumping \\
\hline 5 & YH-54 & YH block & 800 & Vertical well & pumping \\
\hline 6 & YH-036 & YH block & 4,512 & Vertical well & pumping \\
\hline 7 & YH-100 & YH block & 101 & Vertical well & pumping \\
\hline 8 & JNP01-2 & YH block & 3,792 & Horizontal well & pumping \\
\hline 9 & YH-054-1 & YH block & 1,440 & Vertical well & pumping \\
\hline 10 & YH-99 & YH block & 6,144 & Vertical well & pumping \\
\hline 11 & YH-29 & YH block & 2,652 & Vertical well & pumping \\
\hline 12 & YH-023 & YH block & 9,288 & Vertical well & pumping \\
\hline 13 & YH-026 & YH block & 8,802 & Vertical well & pumping \\
\hline 14 & YH-011 & YH block & 5,404 & Vertical well & pumping \\
\hline 15 & YH-010 & YH block & 3,144 & Vertical well & pumping \\
\hline 16 & YH-006 & YH block & 4,800 & Vertical well & pumping \\
\hline 17 & YH-007 & YH block & 141 & Vertical well & pumping \\
\hline 18 & YH-13-04 & YH block & 0 & Vertical well & pumping \\
\hline 19 & YH-13-01 & YH block & 0 & Vertical well & pumping \\
\hline 20 & YH-13-18 & YH block & 0 & Vertical well & pumping \\
\hline 21 & JS-14 & YH block & 0 & Vertical well & pumping \\
\hline 22 & JS-055 & YH block & 50 & Vertical well & pumping \\
\hline 23 & JS-056 & YH block & 3,216 & Vertical well & Flowing \\
\hline 24 & JS-100 & YH block & 2,832 & Vertical well & pumping \\
\hline 25 & JS-58 & YH block & 6,720 & Vertical well & pumping \\
\hline 26 & JS-050 & YH block & 163 & Vertical well & Flowing \\
\hline 27 & JS-051 & YH block & 2,352 & Vertical well & pumping \\
\hline 28 & JS-49 & YH block & 150 & Vertical well & pumping \\
\hline 29 & SHx-161 & YH block & 2,643 & Vertical well & Flowing \\
\hline 30 & JS-052 & YH block & 65 & Vertical well & pumping \\
\hline 31 & JS-165 & YH block & 2,176 & Vertical well & pumping \\
\hline 32 & JS-048 & YH block & 3,056 & Vertical well & pumping \\
\hline 33 & ZH-62 & ZH block & 1,440 & Vertical well & pumping \\
\hline 34 & ZH-57 & ZH block & 1,608 & Vertical well & Flowing \\
\hline 35 & ZH-009-4 & ZH block & 360 & Cluster well & pumping \\
\hline 36 & ZH-009-3 & ZH block & 336 & Cluster well & pumping \\
\hline 37 & ZH-009-2 & ZH block & 624 & Cluster well & pumping \\
\hline 38 & ZH-50-4 & ZH block & 120 & Cluster well & pumping \\
\hline 39 & ZH-50-3 & ZH block & 192 & Cluster well & pumping \\
\hline
\end{tabular}


Table 1. Continued.

\begin{tabular}{|c|c|c|c|c|c|}
\hline 40 & ZH-50-2 & ZH block & 240 & Cluster well & pumping \\
\hline 41 & ZH-50-1 & ZH block & 120 & Cluster well & pumping \\
\hline 42 & ZH-88 & ZH block & 2,456 & Vertical well & pumping \\
\hline 43 & ZH-119 & ZH block & 2,880 & Vertical well & pumping \\
\hline 44 & ZH-103 & ZH block & 384 & Vertical well & pumping \\
\hline 45 & ZH-120 & ZH block & 888 & Vertical well & pumping \\
\hline 46 & ZH-137 & ZH block & 1,200 & Vertical well & pumping \\
\hline 47 & ZH-104 & ZH block & 1,104 & Vertical well & pumping \\
\hline 48 & ZH-122 & ZH block & 720 & Vertical well & pumping \\
\hline 49 & ZH-105 & ZH block & 1,248 & Vertical well & pumping \\
\hline 50 & ZH-91 & ZH block & 96 & Vertical well & pumping \\
\hline 51 & ZH-92 & ZH block & 4,416 & Vertical well & pumping \\
\hline 52 & ZH-214 & ZH block & 50 & Vertical well & pumping \\
\hline 53 & ZH-182 & ZH block & 336 & Vertical well & pumping \\
\hline 54 & ZH-181 & ZH block & 312 & Vertical well & pumping \\
\hline 55 & ZH-193 & ZH block & 624 & Vertical well & pumping \\
\hline 56 & ZH-192 & ZH block & 1,080 & Vertical well & pumping \\
\hline 57 & ZH-179 & ZH block & 1,896 & Vertical well & pumping \\
\hline 58 & ZH-453 & ZH block & 0 & Vertical well & pumping \\
\hline 59 & ZH-191 & ZH block & 288 & Vertical well & pumping \\
\hline 60 & ZH-178 & ZH block & 504 & Vertical well & pumping \\
\hline 61 & ZH-166 & ZH block & 504 & Vertical well & pumping \\
\hline 62 & ZH-169 & ZH block & 48 & Vertical well & pumping \\
\hline 63 & ZH-168 & ZH block & 48 & Vertical well & pumping \\
\hline 64 & ZH-156 & ZH block & 0 & Vertical well & pumping \\
\hline 65 & ZH-149 & ZH block & 240 & Vertical well & pumping \\
\hline 66 & ZH-161 & ZH block & 0 & Vertical well & pumping \\
\hline 67 & ZH-148 & ZH block & 0 & Vertical well & pumping \\
\hline 68 & ZH-159 & ZH block & 0 & Vertical well & pumping \\
\hline 69 & ZH-145 & ZH block & 0 & Vertical well & pumping \\
\hline 70 & ZH-128 & ZH block & 504 & Vertical well & pumping \\
\hline 71 & ZH-144 & ZH block & 984 & Vertical well & pumping \\
\hline 72 & ZH-153 & ZH block & 768 & Vertical well & pumping \\
\hline 73 & ZH-142 & ZH block & 240 & Vertical well & pumping \\
\hline 74 & ZH-126 & ZH block & 0 & Vertical well & pumping \\
\hline 75 & HD-114 & HD block & 1,668 & Vertical well & pumping \\
\hline 76 & HD-101 & HD block & 3,445 & Vertical well & Flowing \\
\hline 77 & HD-096 & HD block & 2,239 & Vertical well & pumping \\
\hline 78 & HD-88 & HD block & 2,568 & Vertical well & pumping \\
\hline 79 & HD-082 & HD block & 4,614 & Vertical well & pumping \\
\hline 80 & HD-090 & HD block & 563 & Vertical well & pumping \\
\hline
\end{tabular}


Table 1. Continued.

\begin{tabular}{|c|c|c|c|c|c|}
\hline 81 & HD-083 & HD block & 4,548 & Vertical well & pumping \\
\hline 82 & HD-070 & HD block & 662 & Vertical well & pumping \\
\hline 83 & HD-063 & HD block & 552 & Vertical well & pumping \\
\hline 84 & HD-055 & HD block & 3,018 & Vertical well & pumping \\
\hline 85 & HD-270 & HD block & 4,257 & Vertical well & pumping \\
\hline 86 & HD-060 & HD block & 1,358 & Vertical well & pumping \\
\hline 87 & HD-065 & HD block & 1,128 & Vertical well & pumping \\
\hline 88 & HD-144 & HD block & 7,488 & Vertical well & pumping \\
\hline 89 & HD-155 & HD block & 5,304 & Vertical well & pumping \\
\hline 90 & HD-145 & HD block & 552 & Vertical well & pumping \\
\hline 91 & HD-138 & HD block & 552 & Vertical well & pumping \\
\hline 92 & HD-254 & HD block & 2,256 & Vertical well & pumping \\
\hline 93 & HD-080 & HD block & 552 & Vertical well & pumping \\
\hline 94 & HD-079 & HD block & 2,616 & Vertical well & pumping \\
\hline 95 & HD-156 & HD block & 504 & Vertical well & pumping \\
\hline 96 & HD-086 & HD block & 672 & Vertical well & pumping \\
\hline 97 & HD-084 & HD block & 1,824 & Vertical well & pumping \\
\hline 98 & HD-168 & HD block & 1,920 & Vertical well & pumping \\
\hline 99 & HD-167 & HD block & 2,808 & Vertical well & pumping \\
\hline 100 & HD-153 & HD block & 408 & Vertical well & pumping \\
\hline 101 & HD-180 & HD block & 1,104 & Vertical well & pumping \\
\hline 102 & HD-203 & HD block & 1,152 & Vertical well & pumping \\
\hline 103 & HD-202 & HD block & 504 & Vertical well & pumping \\
\hline 104 & HD-201 & HD block & 1,032 & Vertical well & pumping \\
\hline 105 & HD-281 & HD block & 1,632 & Vertical well & pumping \\
\hline 106 & HD-092 & HD block & 1,656 & Vertical well & pumping \\
\hline 107 & HD-188-2 & HD block & 240 & Vertical well & pumping \\
\hline 108 & HD-085 & HD block & 1,680 & Vertical well & pumping \\
\hline 109 & HD-260 & HD block & 1,488 & Vertical well & pumping \\
\hline 110 & HD-226 & HD block & 1,056 & Vertical well & pumping \\
\hline 111 & HD-225 & HD block & 2,760 & Vertical well & pumping \\
\hline 112 & HD-241 & HD block & 0 & Vertical well & pumping \\
\hline 113 & HD-240 & HD block & 408 & Vertical well & pumping \\
\hline
\end{tabular}

\section{Experimental Methods}

Well Selection

This study selected 113 wells and took into account geological conditions, production technologies, running states, and gas production rates. Three different blocks (YH, ZH, and HD), were randomly selected to compare different geological conditions. Production technologies included vertical, cluster, and horizontal wells. Running states took into account flowing wells and regular pumping wells. Well production rates are provided in Table 1.

\section{System Boundary}

This research study focused on the well pad at each sampling site, including the area around the wellhead (usually fenced) that contains the surface equipment 


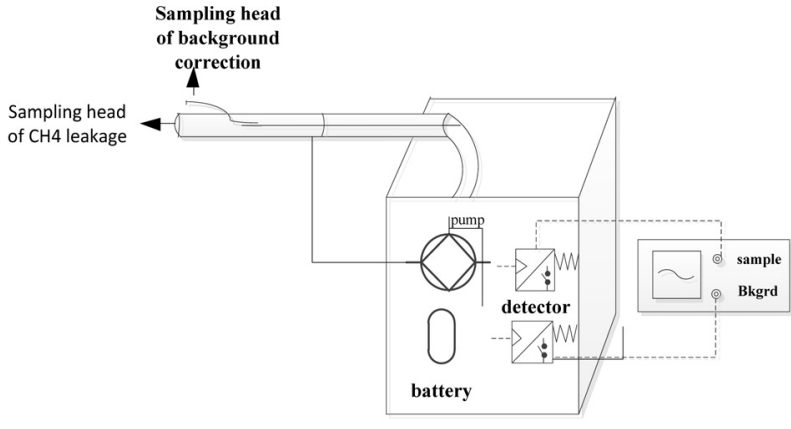

Fig. 3. Work flow of the Hi Flow Sampler.

associated with CBM production. This includes the tubing, water outlet, flange, sealing, connection, and other components. Leakage from these components can occur in several ways. First, methane leakage from tubing is caused by the abrasion of sucker rod and tubing strings. Second, leakage through water outlets is caused when the gas pressure is too high, resulting in CBM dissolution into the water in a super-saturated state. This situation causes the $\mathrm{CBM}$ to be drawn into the oil tubing, where the imbalance of pressure inside and outside the tubing will release a portion of the CBM. Third, other leakage may result from sealing problems in the flanges, seals, connections, valves, and other components.

\section{Monitoring $\mathrm{CH}_{4}$ Leakage from Tubing}

$\mathrm{CH}_{4}$ leakage from tubing was measured using a Hi Flow Sampler during normal operating conditions. The sampler was deployed as close to the leak point as possible, normally less than $10 \mathrm{~cm}$. The monitoring time was 2 to $10 \mathrm{~min}$ and the detection range was $1.42 \mathrm{l} / \mathrm{min}$ to 226 1/min. Fig. 3 shows the measuring procedure.

First, air around the leak point was pumped into the sampler using a negative pressure pump. A Venturi meter measured gas flow. Then the gas was fed into a catalytic combustor, where an ion flow was produced by organic gas combustion. The methane concentration was then measured by examining the ion flow using a flame ionization detector (FID).

An ambient background air sample was collected around each examined well during the sampling event to assess background levels of methane. Leakage was calculated using the following equation:

$$
\mathrm{M}=\left(\mathrm{S}_{1}-\mathrm{S}_{0}\right) / \mathrm{t}
$$

...where $\mathrm{M}(1 / \mathrm{min})$ is methane leakage, $\mathrm{S}_{1}(1)$ is methane leakage at the leak point, $S_{0}(1)$ is the background methane level, and $\mathrm{T}(\mathrm{min})$ is the monitoring time.

\section{Monitoring $\mathrm{CH}_{4}$ Leakage from Water Outlet}

A pretreatment device was constructed to prevent droplets and ashes from entering the Hi Flow Sampler. The device is $15 \mathrm{~mm} \times 15 \mathrm{~mm} \times 40 \mathrm{~mm}$ and made with UPVC material (Fig. 4). Water outlets were connected to P2 piping using an elastic hose sealed with adhesive. Gas and water were separated in the fabricated pretreatment device. The gas entered the Hi Flow Sampler through the $\mathrm{P} 1$ piping that was filled with silicone to minimize moisture. The P3 was a water-draining switch.
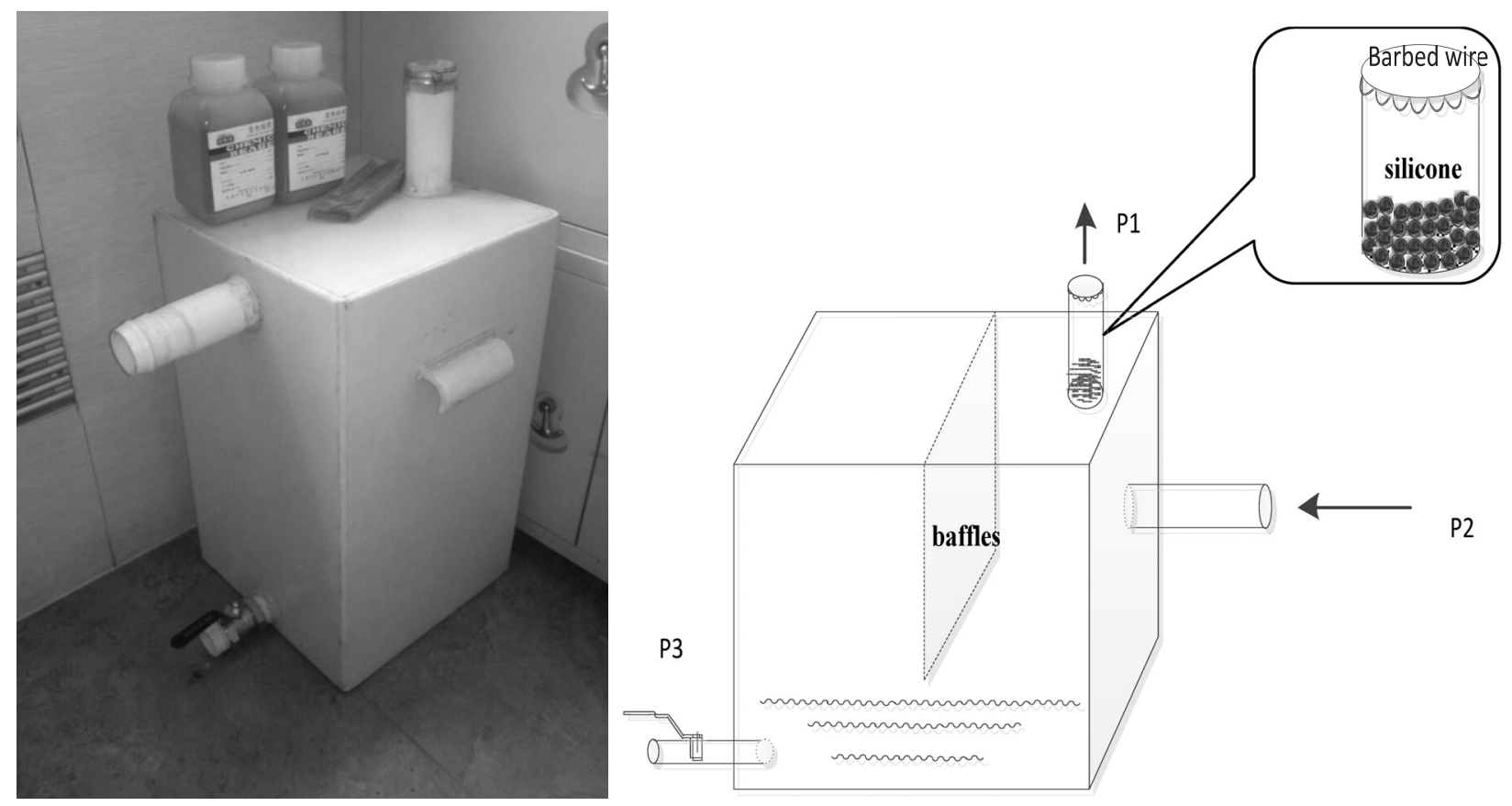

Fig. 4. Work flow of the self-made pretreatment. 


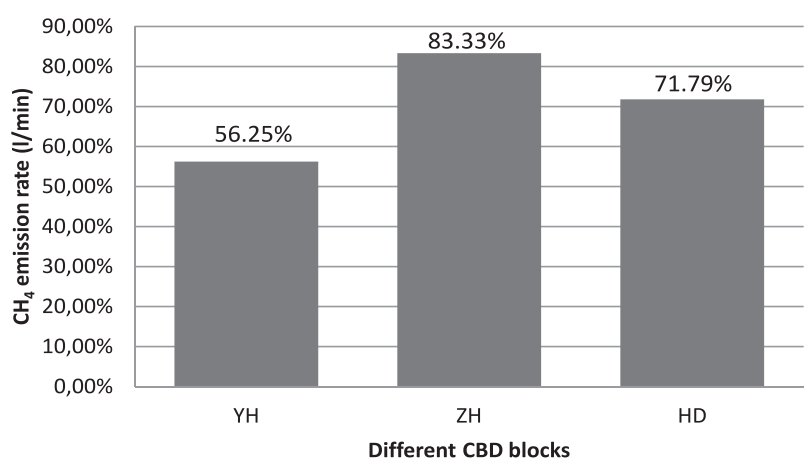

Fig. 5. $\mathrm{CH}_{4}$ leak rates of the different blocks from the tubing.

\section{Monitoring $\mathrm{CH}_{4}$ Leakage \\ from Other Components}

There were two steps taken to monitor $\mathrm{CH}_{4}$ leakage from other components. First, a remote methane leak detector detected the leak point. Second, the Hi Flow Sampler measured the leakage at the leak point.

\section{Results and Discussion}

\section{$\mathrm{CH}_{4}$ Leakage from Tubing}

Fig. 5 summarizes the tubing leakage rate at the different blocks. The leakage rate of the $\mathrm{ZH}$ block was the highest, at $83.33 \%$. The HD block was the next highest, at $71.79 \%$. The YH block leakage rate was lowest, at $56.25 \%$. The average leakage rate across all three blocks was $70.46 \%$.

Fig. 6 shows the leakage volume of different blocks. The leakage from wells in the $\mathrm{YH}$ block ranged from 0.1 to $7.63 \mathrm{l} / \mathrm{min}$; the average was $1.52 \mathrm{l} / \mathrm{min}$. The leakage from wells in the $\mathrm{ZH}$ block ranged from 0.2 to $32.75 \mathrm{l} / \mathrm{min}$; the average was $5.44 \mathrm{l} / \mathrm{min}$. The leakage from wells in the HD block ranged from 0.2 to $44.31 / \mathrm{min}$; the average was $6.72 \mathrm{l} / \mathrm{min}$. The average across all 113 wells was $4.77 \mathrm{l} / \mathrm{min}$.

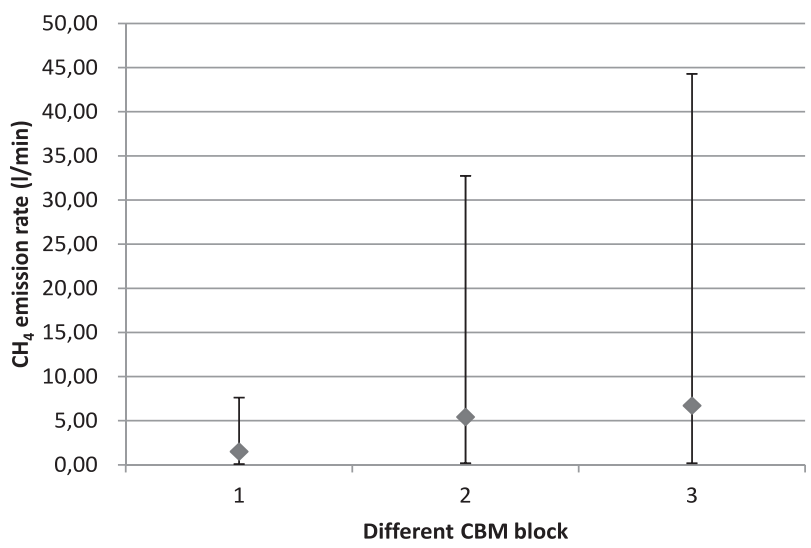

Fig. 6. $\mathrm{CH}_{4}$ leak volume rates of the different blocks from the tubing.

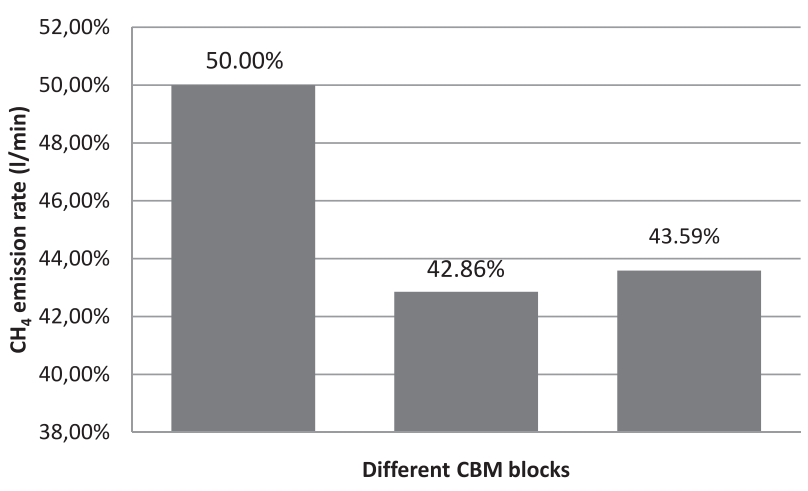

Fig. 7. $\mathrm{CH}_{4}$ leak rates of the different blocks from the water outlet.

As discussed above, the leakage rate and the leakage volume of the YH block was the lowest; values were higher for $\mathrm{ZH}$ and HD blocks. There was considerable variation in average leakage across blocks, indicated by a large standard deviation in measurements. The high leakage in $\mathrm{ZH}$ and HD blocks was associated with particular geological conditions: rock strength is weak and easily collapses, leading to tilting and excessive tubing wear. Poor management practices aggravate the problem, resulting in problematic and damaged tubing not being replaced in a timely manner. Conversely, the geological conditions in the YH block are relatively stable, and regular and effective tubing management contributes to a low number of leakage points and a low leak rate. In summary, the leakage rate and the leakage volume of different wells were closely related to the management level.

\section{$\mathrm{CH}_{4}$ Leakage from the Water Outlets}

Fig. 7 shows the water outlet leakage rate of different blocks. The leakage rate of the TH block was the highest, at more than $50 \%$. The HD block was the next highest, at $43.59 \%$. The $\mathrm{ZH}$ block was the lowest, at $42.86 \%$.

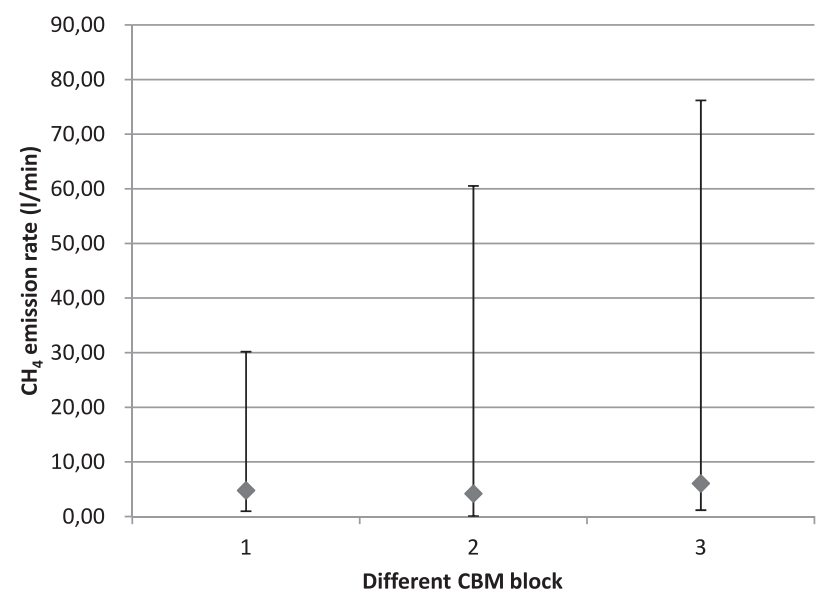

Fig. 8. $\mathrm{CH}_{4}$ leak volume rates of the different blocks from the water outlet. 


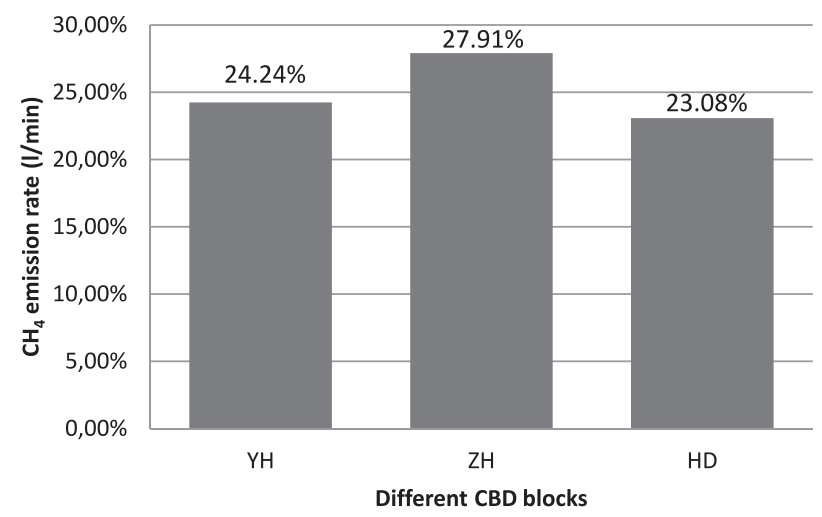

Fig. 9. $\mathrm{CH}_{4}$ leak rates of the different blocks from the other components.

The average leakage rate is $45.48 \%$ for the water outlets, below the average for the tubing.

Fig. 8 shows the water outlet leakage volume of the different blocks. Leakage from wells in the $\mathrm{YH}$ block ranged from 1.00 to $30.20 \mathrm{l} / \mathrm{min}$; the average was $4.80 \mathrm{l} / \mathrm{min}$. Leakage from wells in the ZH block ranged from 0.10 to $60.55 \mathrm{l} / \mathrm{min}$; the average was $4.22 \mathrm{l} / \mathrm{min}$. Leakage from wells in the HD block was between 1.20 and $76.20 \mathrm{l} / \mathrm{min}$; the average was $6.07 \mathrm{l} / \mathrm{min}$. The average of the water outlet leakage rate across all wells was $5.02 \mathrm{l} / \mathrm{min}$, slightly more than seen in the tubing. An unusually large leakage rate from a subset of the wells caused the higher average leakage from the water outlets.

The water outlet leakage rate and volume for each of the blocks showed little differences. The leakage rate in $\mathrm{YH}$ block wells was relatively high, as was the leakage volume in the ZH block. The main cause for the difference was that the CBM content in YH block was high; the gas dissolved into water at a super saturated state, which leaked into the oil tubing. Conversely, the $\mathrm{HD}$ and $\mathrm{ZH}$ blocks were larger and had relatively complex geological conditions, with large differences in CBM that led to leakage variation.

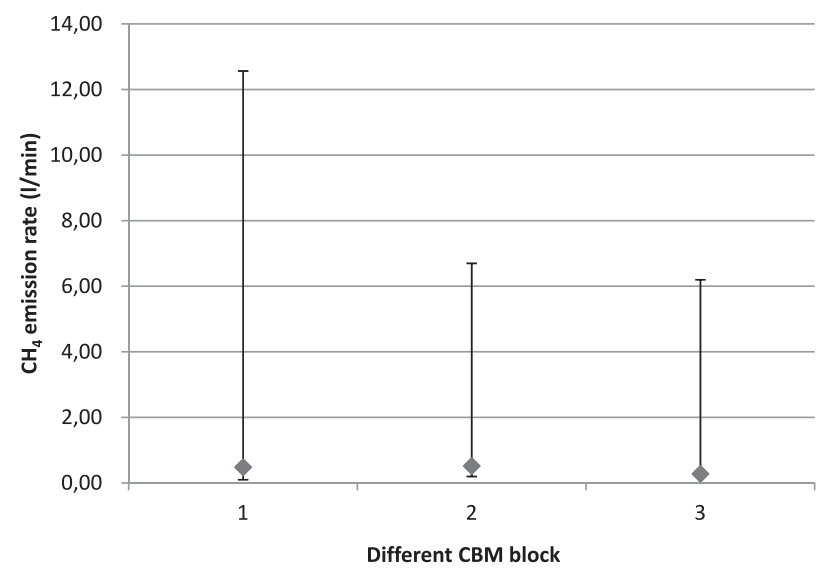

Fig. 10. $\mathrm{CH}_{4}$ leak volume rates of the different blocks from the other components.

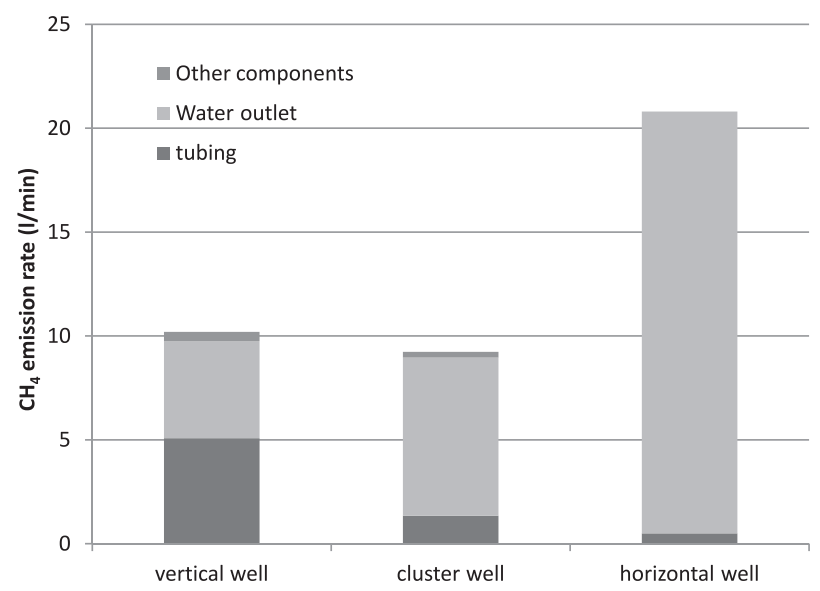

Fig. 11. $\mathrm{CH}_{4}$ leak rates of the different processes.

\section{$\mathrm{CH}_{4}$ Leakage from Other Components}

Fig. 9 shows the leakage through other well components across the different blocks. The leakage in $\mathrm{ZH}$ block wells was the highest, at $27.91 \%$. The YH block was the next highest, at $24.24 \%$. The HD block well had the lowest rate, at $23.08 \%$. Fig. 10 shows the leakage volume through other components in the different blocks. The leakage volume in the YH block ranged from 0.10 to $12.57 \mathrm{l} / \mathrm{min}$; the average was $0.48 \mathrm{l} / \mathrm{min}$. The leakage volume in the $\mathrm{ZH}$ block well ranged from 0.20 to $6.70 \mathrm{l} / \mathrm{min}$; the average was $0.52 \mathrm{l} / \mathrm{min}$. The leakage volume in the HD block ranged from 0.20 to $6.201 / \mathrm{min}$; the average was $0.28 \mathrm{l} / \mathrm{min}$. The average across all wells was $0.43 \mathrm{l} / \mathrm{min}$.

As discussed above, the leakage rate and volume through other well components were significantly below the tubing and the water outlets, and there was little variability across different blocks. Leakage of methane through other well components is mainly due to the sealing of the pressure meters and connection parts. Leakage was mainly associated with equipment servicing and overhaul schedules.

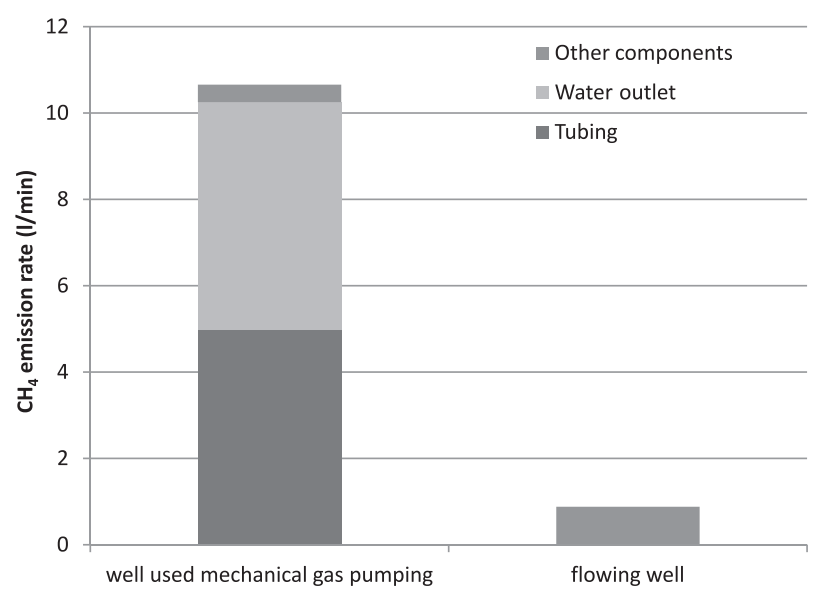

Fig. 12. $\mathrm{CH}_{4}$ leak rates of the different running states. 


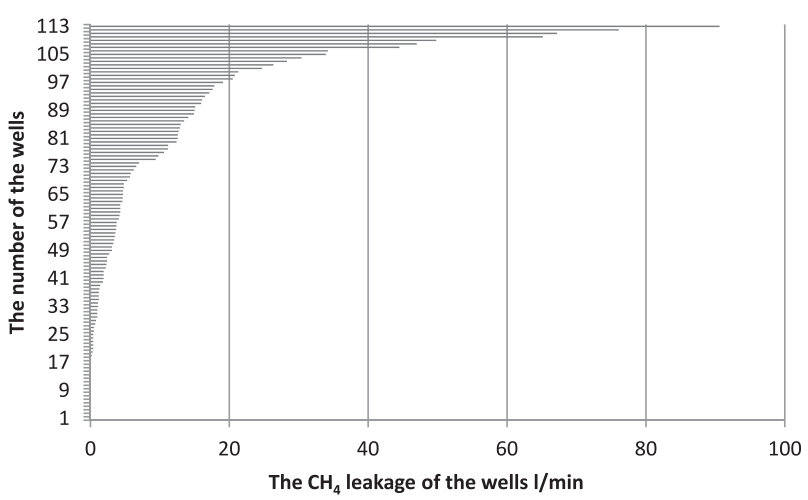

Fig. 13. $\mathrm{CH}_{4}$ leak rates of all wells.

\section{$\mathrm{CH}_{4}$ Leakage of Different Processes}

Of the 113 wells studied, 104 were vertical wells, eight were cluster wells, and one was a horizontal well. As Fig. 11 shows, leakage from the single horizontal well was the highest, with an average leakage of $20.80 \mathrm{l} / \mathrm{min}$. Water outlet leakage accounted for $97.60 \%$ of the total leakage from this well. The average leakage volume of the 104 vertical wells was the next highest, with an average of $10.20 \mathrm{l} / \mathrm{min}$. Here, the water outlets and tubing accounted for $95.66 \%$ of the total leakage. The leakage was the lowest in the cluster wells, with an average of $9.241 / \mathrm{min}$. In these eight wells, $82.47 \%$ of the leakage was from the water outlets.

Leakage from the cluster and horizontal wells was mainly through water outlets, with relatively low leakage from tubing and other components. This low leakage may be because the cluster and the horizontal wells are newly constructed, thereby minimizing damage, wear, and poor management. The leakage from water outlets was likely high because of the cluster and horizontal wells' large contact areas between the coal bed and the pit-shaft. The coal bed drain discharge and the dissolved gas emission are larger, and the drain discharge of newly constructed wells during the first three years is at a relatively high level, leading to a correspondingly high volume of methane leakage.

\section{$\mathrm{CH}_{4}$ Leakage of the Different Running States}

Of the 113 wells sampled, 108 are mechanical-gas pumping and five are natural-flowing wells. As Fig. 12 shows, the average leakage from mechanical gas pumping wells was $10.671 / \mathrm{min}$, which includes leakage from tubing, water outlets, and other components. The average leakage from the natural flowing wells was $0.881 / \mathrm{min}$, far below the mechanical-gas pumping wells.

\section{$\mathrm{CH}_{4}$ Leakage and Emission Factors of CBM Well}

This study integrated the monitoring of tubing, water outlet, and other component leakage across 113 wells. Fig. 13 shows that leakages ranged from 0 to $90.60 \mathrm{l} / \mathrm{min}$ across all wells, with the average leakage $10.22 \mathrm{l} / \mathrm{min}$. When considering all the wells: 17 wells $(15.04 \%$ of all wells) had no $\mathrm{CH}_{4}$ leakage, 58 wells $(51.33 \%$ of all wells) had a single well leakage of less than $101 / \mathrm{min}$, and 97 wells ( $85.84 \%$ of all monitored wells) had a single well leakage less than $20 \mathrm{l} / \mathrm{min}$.

This study analyzed gas measurements from 113 wells, with an average gas production of $1,752 \mathrm{~m}^{3} / \mathrm{d}$. $\mathrm{CH}_{4}$ emissions were released through tubing, water outlets, and other components. As Table 2 shows, tubing leakage was nearly equal to water outlet leakage, at $4.77 \mathrm{l} / \mathrm{min}$ and 5.02 $1 /$ min, respectively. Both were above the leakage of other components, at $0.43 \mathrm{l} / \mathrm{min}$. In addition, the variability in tubing leakage (measured using standard deviation) was the highest, with leakage ranging from 0 to $44.30 \mathrm{l} / \mathrm{min}$. Wells with good geological conditions and scientific management showed low leakage; wells with unfavorable geological conditions and improper management had much higher leakage. The variability in water outlet leakage was the next highest; variability across other components was the lowest.

Emission factors were calculated based on the average gas production and average leakage across wells. The emission factors of tubing, water outlets, and other components were 82.14, 86.45, and $86.45 \mathrm{~kg}$ $\mathrm{CO}_{2}$-e $\mathrm{t}^{-1}$, respectively. The total emission factor was $176 \mathrm{~kg}$ $\mathrm{CO}_{2}-\mathrm{e} \mathrm{t}^{-1}-$ far above the Australian emission level at $11.7 \mathrm{~kg} \mathrm{CO}_{2}-\mathrm{e} \mathrm{t}^{-1}$.

\section{Conclusions}

This study found that methane leakage from wells in the Qinshui Basin of Shanxi Province in northern China is mainly caused by leaks from water outlets and tubing. These two types of leakage account for $95.79 \%$ of total leakage, with a large standard deviation of 12.28 . The

Table 2. CH4 emission factors of tubing, water outlet, and other components.

\begin{tabular}{|c|c|c|c|c|}
\hline & Units & Tubing & Water outlet & Other components \\
\hline Mean & $1 / \mathrm{min}$ & 4.77 & 5.02 & 0.43 \\
\hline Median & $1 / \mathrm{min}$ & 0 & 1 & 0 \\
\hline Std Deviation & - & 12.28 & 8.05 & 1.53 \\
\hline Factor & $\mathrm{Kg} \mathrm{CO}_{2}-\mathrm{e} \mathrm{t}^{-1}$ & 82.33 & 86.65 & 7.42 \\
\hline
\end{tabular}


primary differences in leakage between well groupings were due to geological conditions and management. Wells with unfavorable geological conditions and improper management had consistently higher leakage. The variability in leakage through water outlets was the next highest, followed by leakage through other components. Different processes and running states on $\mathrm{CH}_{4}$ leakage have the greatest effects on leakage. Horizontal well leakage was highest in this study, with an average of $20.80 \mathrm{l} / \mathrm{min}$. The average leakage of naturally flowing wells was $0.88 \mathrm{l} / \mathrm{min}$, below that of wells stimulated through mechanical-gas pumping. The comprehensive emission factor across the 113 monitored wells was $176 \mathrm{~kg}$ $\mathrm{CO}_{2}$-e $\mathrm{t}^{-1}$, which is above the Australian emission level of $11.7 \mathrm{~kg} \mathrm{CO}_{2}-\mathrm{e} \mathrm{t}^{-1}$.

\section{Acknowledgements}

This study was sponsored by the Joint Fund of the Shanxi Science and Technology Department and Jincheng Anthracite Mining Group.

\section{References}

1. YUN J., XU F.Y., LIU L., ZHONG N.N., WU X.B. New progress and future prospects of CBM exploration and development in China. Inter. J. Min. Sci. Tech. 22 (3), 363, 2012.
2. HAMAWAND I., YUSAF T., HAMAWAND S.G. Coal seam gas and associated water: A review paper. Renew. Sust. Energ. Rev. 22, 550, 2013.

3. GOLDING S.D., RUDOLPH V., FLORES R.M. COenhanced coal bed methane. Int. J. Coal Geol. 82 (3-4), 133, 2010.

4. FAN Y., MA J., ZhU L. Evaluating coal bed methane investment in China based on a real options model. Resour. Policy. 38 (1), 50, 2013.

5. LIAO Y.Y., LUO D.D., LI W.L. Development strategy analysis of China's CBM. Acta Petrolei Sci. 33, 1098, 2012.

6. LUO D.K., DAI Y.J., XIA L.Y. Economic evaluation based policy analysis for coalbed methane industry in China. Energy. 36 (1), 360, 2011.

7. DEMARTY M., BASTIEN J. GHG emissions from hydroelectric reservoirs in tropical and equatorial regions: Review of 20 years of $\mathrm{CH}_{4}$ emission measurements. Energ Policy. 39 (7), 4197, 2011.

8. DE RICHTER R., CAILLOL S. Fighting global warming: The potential of photocatalysis against $\mathrm{CO}_{2}, \mathrm{CH}_{4}, \mathrm{~N}_{2} \mathrm{O}$, CFCs, tropospheric $\mathrm{O}_{3}, \mathrm{BC}$ and other major contributors to climate change. J. Photoch. Photobio. C. 12 (1), 1, 2011.

9. HEATH G., MELDRUM J., FISHER N., ARENT D., BAZILIAN M. Life cycle greenhouse gas emissions from Barnett Shale gas used to generate electricity. J. Unconv. Oil Gas Resour. 8, 46, 2014.

10. BRANTLEY S.L., YOXTHEIMER D., ARJMAND S., GRIEVE P., VIDIC R., POLLAK J., Llewellyn G.T., Abad J., Simon C. Water resource impacts during unconventional shale gas development: The Pennsylvania experience. Int. J. Coal Geol. 126, 140, 2014.

11. LAURENCE S., ADISA A. Life cycle environmental impacts of UK shale gas. Appl. Energy. 134, 506, 2014. 